\title{
PREPARATION AND APPLICATION OF MODIFIED MONTMORILLONITE DISPERSION FOR CHROME-LESS TANNING OF LEATHER
}

\author{
Maryna ZHALDAK*, Olena MOKROUSOVA
}

Kyiv National University of Trade and Economics, Kyoto str., 19, 02156, Kyiv, Ukraine, maryna070992@ukr.net

Received: 09.03.2020

Accepted: 29.06 .2020

https://doi.org/10.24264/Ifj.20.3.7

PREPARATION AND APPLICATION OF MODIFIED MONTMORILLONITE DISPERSION FOR CHROME-LESS TANNING OF LEATHER

ABSTRACT. The properties of modified montmorillonite dispersions for their use in the chrome-less leather tanning method were investigated. It is proposed to modify montmorillonite with aluminum compounds and to combine the obtained dispersions with chromium compounds for leather treatment. Modification of montmorillonite dispersions by aluminum compound within 5.0-7.0\% Al2O3 of the weight of the mineral contributes to obtaining the most stable positively charged montmorillonite dispersions. The use of the obtained montmorillonite dispersions is effective for stabilizing the collagen structure and increasing the temperature resistance of collagen. The use of modified montmorillonite dispersions combined with a chromium tanning agent contributes to the introduction of chrome-less tanning. $0.75 \%$ of $\mathrm{Cr} 2 \mathrm{O} 3$ and $3.0 \%$ of modified dispersion of montmorillonite of the weight of the pelts in conversion for mineral weight are considered the optimal consumption of chromium tanning agent.

KEY WORDS: tanning, montmorillonite, potassium aluminum sulfate, modification, dispersion, collagen, leather properties.

PREPARAREA ȘI APLICAREA UNEI DISPERSII DE MONTMORILONIT MODIFICATE PENTRU TĂBĂCIREA FĂRĂ CROM A PIELII

REZUMAT. S-au investigat proprietățile dispersiilor de montmorilonit modificate pentru utilizarea acestora într-o metodă de tăbăcire a pielii fără crom. Se propune modificarea montmorilonitului cu compuși din aluminiu și combinarea dispersiilor obținute cu compuși de crom pentru tratarea pielii. Modificarea dispersiilor de montmorilonit cu compusul de aluminiu în proporție de 5.0-7.0\% Al2O3 relativ la greutatea mineralului contribuie la obținerea celor mai stabile dispersii de montmorilonit încărcate pozitiv. Utilizarea dispersiilor de montmorilonit obținute este eficientă pentru stabilizarea structurii colagenului și pentru creșterea rezistenței la temperatură a acestuia. Utilizarea dispersiilor de montmorilonit modificate combinate cu un agent de tăbăcire pe bază de crom contribuie la introducerea metodei de tăbăcire fără crom. Proporțiile de $0,75 \%$ Cr2O3 și 3,0\% dispersie de montmorilonit modificată din greutatea pieilor gelatină relativ la greutatea mineralului sunt considerate consumul optim de agent de tăbăcire.

CUVINTE CHEIE: tăbăcire, montmorilonit, sulfat dublu de aluminiu și potasiu, modificare, dispersie, colagen, proprietățile pielii

PRÉPARATION ET APPLICATION D'UNE DISPERSION MODIFIÉE DE MONTMORILLONITE POUR LE TANNAGE DU CUIR SANS CHROME RÉSUMÉ. Les propriétés des dispersions modifiées de montmorillonite pour leur utilisation dans la méthode de tannage du cuir sans chrome ont été étudiées. Il est proposé de modifier la montmorillonite avec des composés d'aluminium et de combiner les dispersions obtenues avec des composés de chrome pour le traitement du cuir. La modification des dispersions de montmorillonite par le composé d'aluminium dans la proportion de 5.0 à $7.0 \%$ d’Al2O3 par rapport au poids du minéral contribue à obtenir les plus stables dispersions de montmorillonite chargées positivement. L'utilisation des dispersions de montmorillonite obtenues est efficace pour stabiliser la structure protéique et augmenter la résistance à la température du collagène. L'utilisation de dispersions modifiées de montmorillonite combinées d'agent de tannage au chrome contribue à l'introduction du tannage sans chrome. Les proportions de $0.75 \%$ de $\mathrm{Cr} 2 \mathrm{O} 3$ et $3.0 \%$ de dispersion modifiée de montmorillonite par rapport au poids de la peau en termes de poids minéral sont considérés comme l'utilisation optimale d'agent de tannage au chrome. MOTS CLÉS : tannage, montmorillonite, disulfate d'aluminium et de potassium, modification, dispersion, collagène, propriétés du cuir

\footnotetext{
" Correspondence to: Maryna ZHALDAK, Kyiv National University of Trade and Economics, Kyoto str., 19, 02156, Kyiv, Ukraine, maryna070992@ukr.net
} 


\section{INTRODUCTION}

The tanning process is essential in stabilizing the collagen structure of the derma [1]. A variety of mineral and organic tanning agents are used for the tanning of the leather. Chrome tanning is the traditional option. The basic chromium sulfate is used in the production of $80 \%$ of leather in use. It is a coordination compound that effectively forms the structure of the derma. Stabilization of collagen structure by chromium compounds occurs through the formation of coordination bonds with carboxyl groups of the protein [2].

A peculiarity of chromium tanning turns out to be an inefficient use of chromium compounds, since almost $40 \%$ of tannins remain in wastewater [3]. Considering the disadvantages of using chromium compounds, scientific research on the replacement and use of rather eco-friendlier substances has been conducted for a long time. Although many papers have been written in this field of research [4-6], this type of research remains relevant due to a wide range of leather materials. Therefore, it is the environmental factor that determines the need to develop and apply chrome-less or chromefree tanning.

One of the directions of ecologization of leather manufacturing is the use of modified montmorillonite dispersions in various technological processes such as tanning, filling, dyeing, fat-liquoring, etc. [79]. This is due to the special colloid-chemical properties of montmorillonite, as the main mineral of bentonite clays. Montmorillonite is an aluminosilicate and has a high exchange capacity [10]. The disorder of the crystal lattice of montmorillonite explains the high ability to disperse its aggregates and to acquire nanoscale particles. Montmorillonite has a well-developed adsorption surface, and its modification with various chemical compounds significantly changes the colloid-chemical properties of its dispersions. As a result of the modification, it is possible to obtain nanocomposites with the required charge, the nature of surface and $\mathrm{pH}$ to ensure effective changes in the structure of the leathers derma.

Thus, studies [11-12] proved the wastewater condition improvement at a leather tannery and the increase of environmentally- friendly manufacturing [11], and the improvement of physical-mechanical properties of leather [12], which testifies to the prospect of the use of montmorillonite for leather treatment.

In the study [13], the authors suggest the use of nanocomposite for leather tanning. The nanocomposite was prepared on the basis of acrylic acid monomers and acrylic aldehyde. Combined use of $6.0 \%$ nanocomposite and chromium tanning agent with a consumption of $0.5 \% \mathrm{Cr}_{2} \mathrm{O}_{3}$ for tanning helps to increase the yield of experimental leather samples in thickness, tensile strength, and reduce the elastic elongation under load.

The effectiveness of leather tanning with the combined use of compositions based on modified montmorillonite dispersions and basic chromium sulfate was investigated in study [14]. To obtain the tanning composition [14], the modification of aqueous dispersion of montmorillonite with sodium carbonate and basic chromium sulfate was carried out. This method of combined tanning helps to reduce the use of chrome tanning agent by $20-25 \%$. The positive effect of using chromium-modified montmorillonite dispersions for tanning [15] indicates the feasibility of their use for the chrome-less tanning. In order to improve the chrome-less tanning of leather, this paper proposes modification of montmorillonite dispersions by aluminum compounds, which will reduce the chromium tanning agent to a greater extent and ensure a higher level of environmental friendliness of the tanning process.

To tackle this problem, studies on the interaction of aluminum sulfate with derma collagen were performed in study [16]. According to the results of previous studies [17], it was found that modification of montmorillonite with aluminum compounds contributes to the change of structural and charge characteristics of mineral dispersions, provides the formation of stable complexes of AI (III) with carboxyl groups of collagen. With further studies, it is advised to determine the optimum consumption of aluminum compounds to modify montmorillonite dispersions and to develop an effective method for chrome-less tanning. 


\section{EXPERIMENTAL}

\section{Materials and Methods}

Bentonite clays from Dashukivsky deposit (Ukraine, Cherkasy oblast) were used for the research. The content of montmorillonite in bentonite clays was $85 \%$.

Potassium aluminum sulfate (aluminum tanning agent), AlK $\left(\mathrm{SO}_{4}\right)_{2} \times 12 \mathrm{H}_{2} \mathrm{O},-$ (Ukraine, Dnipro) - crystals of clear texture, colorless and water soluble crystals (aluminum oxide (III) content - 20.1\%).

The basic chromium sulphate (chromium tanning agent), basicity $\mathrm{OH} / \mathrm{Cr}=1.5, \mathrm{Cr}_{2}\left(\mathrm{SO}_{4}\right)$ ${ }_{n}(\mathrm{OH})_{6-2 n}$ - (Kazakhstan, Aktiubinsk plant of chromium compounds) is a green powder, well soluble in water. The content of chromium oxide (III) is $25.6 \%$ and the dry residue is $89.49 \%$.

Gelatin acid method of production, whose amino acid composition is close to collagen was used as model preparation for the study of chemical interactions of the modified dispersions of montmorillonite with the functional groups of collagen. Gelatine of SER (Ukraine, Lisichanskiy Gelatin Factory) was used for the investigation. The properties of gelatin (GOST 11293-89): particle size $<5 \mathrm{~mm}$; $\mathrm{pH}$ in soluble state in amount of $1.0 \%=5.6 \pm 0.1 \%$, protein content $=83.32 \pm 0.03 \%$; ash $=1.38 \pm 0.01 \%$; moisture content $=15.3 \pm 0.1 \%$.

\section{Preparation of Modified Montmorillonite Dispersion}

Montmorillonite dispersions were modified sequentially. Initially, it was planned to convert the Ca-form of montmorillonite to the Na-form of montmorillonite to disperse mineral aggregates. Next, modification by hydroxocomplexes of multicharged metals was carried out in order to change the sign of the charge on the montmorillonite surface and to give the necessary nature to its surface. Firstly, the aqueous dispersion of montmorillonite at a concentration of $100 \mathrm{~g} / \mathrm{l}$ was treated with sodium carbonate. The consumption of sodium carbonate was $6 \%$ of the weight of the dry mineral. Sodium carbonate was added to the aqueous dispersion of montmorillonite as a 10 $\%$ solution. The montmorillonite dispersion was thoroughly stirred at $50-60^{\circ} \mathrm{C}$ for 3 hours. The stirring speed on a mechanical stirrer was 1500 rpm. The $\mathrm{pH}$ of the dispersion of montmorillonite sodium form (MMTNa) was 7.0-7.5. Secondly, potassium aluminum sulfate of the weight of dry mineral in conversion for $\mathrm{Al}_{2} \mathrm{O}_{3}$ was added to the dispersion of montmorillonite sodium form. The montmorillonite dispersions treated with the aluminum compounds were mixed thoroughly and left for $24 \mathrm{~h}$ to complete the ion exchange processes, the $\mathrm{pH}$ of the modified montmorillonite dispersions ( $\mathrm{MMT}_{\mathrm{Al}}$ ) is 3.5-4.0.

\section{Rheological Properties of Montmorillonite Dispersion}

The efficiency of sequential modification of montmorillonite and the change in the colloidchemical properties of its modified dispersions were investigated by rheological characteristics. The rheological measurements of mineral dispersions were performed on a rotational coaxial viscometer Rheotest-2 (Germany) in the range of shear rates $\gamma=0-1312 c^{-1}$ at temperatures of $20 \pm 0.5^{\circ} \mathrm{C}$. Montmorillonite dispersions were prepared for the experiment, the modification of which was carried out by potassium aluminum sulfate in conversion for $\mathrm{Al}_{2} \mathrm{O}_{3}(0.5 ; 1.0 ; 2.0 ; 4.0 ; 7.0 ; 10.0) \%$ of the weight of the mineral. The structural changes of the modified montmorillonite dispersions $\mathrm{MMT}_{\mathrm{Al}}$ were evaluated by the change in plastic viscosity.

\section{Adsorption Aluminum Compounds on Surface of Montmorillonite}

The adsorption of aluminum compounds on $\mathrm{MMT}_{\mathrm{Na}}$ was studied using a ULAB 102UV spectrophotometer (China). To the same sample $(0.5 \mathrm{~g}) \mathrm{MMT}_{\mathrm{Na}}$ in the form of $20 \%$ paste, was added to $50 \mathrm{ml}$ of potassium aluminum sulfate solution. Consumption of potassium aluminum sulfate was (1.0; 2.0; 4.0; 7.0; 10.0; 20.0) \% $\mathrm{Al}_{2} \mathrm{O}_{3}$ of the weight of the mineral. Dispersion systems were periodically shaken for $\mathbf{2 4}$ hours. The solid phase was separated from the liquid using an OPN-8 centrifuge at a speed of $8000 \mathrm{rpm} /$ min. The equilibrium concentration of $\mathrm{Al}_{2} \mathrm{O}_{3}$ in solution was then determined using a previously obtained calibration curve. The amount of adsorption $(A)$ was calculated by the formula (1):

$$
\mathrm{A}=\frac{\left(\mathrm{C}_{0}-\mathrm{C}_{e}\right) \times V}{m} \text {, }
$$


where, $\mathrm{C}_{0}$ and $\mathrm{C}_{\mathrm{e}}$ - are the initial and equilibrium concentrations of $\mathrm{Al}_{2} \mathrm{O}_{3} \mathrm{~g} / \mathrm{l}$;

$\mathrm{V}$ - volume of solution, l; $\mathrm{m}$ - is the mass of montmorillonite, g.

\section{The Melting Temperature of the Gelatin}

The influence of $\mathrm{MMT}_{\mathrm{Al}}$ on structural transformation of the derma was investigated by the melting temperature of gelatin. The melting temperature of gelatin was used to justify the potential tanning effect of modified montmorillonite dispersions. A $5 \%$ of gelatin solution was prepared for the study. The gelatin solution was introduced into heat-resistant tubes and then added tannins of various types and costs, shaken thoroughly and left to solidify. After freezing, the jelly gelatin was heated in a water bath at a rate of $3^{\circ} \mathrm{C} / \mathrm{min}$ and the melting temperature of the jelly gelatin was fixed.

Exploration of the melting temperature of gelatin of the following samples was performed in order to compare the tanning effect of aluminum compounds and modified montmorillonite dispersions: gelatin after treatment with potassium aluminum sulfate $(\mathrm{G}+\mathrm{Al})$; gelatin after treatment with potassium aluminum sulfate and sodium formate for fixing tannins of aluminum compounds ( $\mathrm{G}+\mathrm{Al}+\mathrm{HCOONa})$; gelatin after treatment with modified montmorillonite dispersions (G+MMT ${ }_{\mathrm{Al}}$ ).

Consumption of potassium aluminum sulfate in conversion for $\mathrm{Al}_{2} \mathrm{O}_{3}$ for experiments $\mathrm{G}+\mathrm{Al}$ and $\mathrm{G}+\mathrm{Al}+\mathrm{HCOONa}$ was formed $(0 ; 1.0$; $2.0 ; 4.0 ; 7.0 ; 10.0 ; 20.0) \%$ of the weight of gelatin. For the $\mathrm{G}+\mathrm{MMT}_{\mathrm{Al}}$ experiment, $\mathrm{MMT}_{\mathrm{Al}}$ consumption (in conversion for dry mineral) was $2.5 \%$ of the weight of gelatin. The consumption of potassium aluminum sulfate for modifying the montmorillonite dispersion in conversion for $\mathrm{Al}_{2} \mathrm{O}_{3}$ was $(0 ; 1.0 ; 2.0 ; 4.0 ; 7.0 ; 10.0 ; 20.0) \%$ of the weight of the mineral.

\section{IR-Spectroscopy}

IR-spectroscopic research was carried out on the Fourier- IR-spectrometer TENSOR-37 (BRUKER, Germany) within 4000-400 $\mathrm{cm}^{-1}$. The character and effectiveness of the interactions of functional groups of montmorillonite with active gelatin groups were evaluated by the change of intensity of light absorption of the corresponding absorption bands. According to sources [18-21], the analysis of vibration bands of absorption in the IR-spectra of resulting substances and the products of their interaction according to frequencies of vibration of characteristic groups of atoms was performed.

The identification of characteristic bands was performed for gelatin (G), gelatin treated with modified montmorillonite dispersions $\left(\mathrm{G}+\mathrm{MMT}_{\mathrm{Al}}\right)$, gelatin treated with chromium tanning agent and modified montmorillonite dispersions $\left(\mathrm{G}+\mathrm{Cr}+\mathrm{MMT}_{\mathrm{Al}}\right)$.

\section{Tanning Application}

Four groups of four samples of goat pelts from $8 \times 15 \mathrm{~cm}$ in size were formed for tanning and determined the effectiveness of the use of modified montmorillonite dispersions. The studied groups of samples were formed using the asymmetric fringe method (pieces of leather were taken from different regions of the leather). The treatment of the pelts was performed on the waste pickling liquid (density $-1.035 \mathrm{~g} / \mathrm{cm}^{3}, \mathrm{pH}$ 2.8). The type of materials and their consumption are presented in Table 1. 
Table 1: Consumption of materials for processing goat pelt

\begin{tabular}{|c|c|c|c|c|}
\hline \multirow{2}{*}{ Material and consumption } & \multicolumn{4}{|c|}{ Variant of treatment } \\
\hline & 1 control & 2 & 3 & 4 \\
\hline Basic chromium sulfate, $\% \mathrm{Cr}_{2} \mathrm{O}_{3}$ & 1.5 & 1.0 & 0.75 & 0.5 \\
\hline Montmorillonite*, $\%$ of the weight of the pelt & - & 2.5 & 3.0 & 3.5 \\
\hline $\begin{array}{l}\text { Potassium aluminum sulfate for modification of montmorillonite, } \% \mathrm{Al}_{2} \mathrm{O}_{3} \text { of the weight } \\
\text { of the mineral }\end{array}$ & - & 5.0 & 5.0 & 5.0 \\
\hline
\end{tabular}

Treatment of the pelts samples for the control and studied options was carried out according to the parameters set out in the Table 2. Treatment option 1 was considered a control sample. The tanning for the control group was carried out by typical technology [22]. Only basic chromium sulfate was used, the consumption of $\mathrm{Cr}_{2} \mathrm{O}_{3}$ formed $1.5 \%$ of the weight of the pelts (Table 2).
The option of treatments 2, 3, 4 was considered experimental and performed in stages. In the first stage of processing basic chromium sulfate with appropriate consumption was used (Table 1). Treatment of the pelts samples was within 60 minutes. In the second stage of tanning, a dispersion of $\mathrm{MMT}_{\mathrm{Al}}$ was added to the liquid with the consumption of the dry mineral weight (Table 1).

Table 2: Parameters of the tanning process

\begin{tabular}{|c|c|c|c|c|c|c|c|c|}
\hline \multirow[t]{2}{*}{ Process } & \multicolumn{2}{|c|}{ Chrome Tanning } & \multicolumn{2}{|c|}{ Chrome-Less Tanning } & \multirow{2}{*}{$\begin{array}{l}\text { Temp, } \\
\text { oc }\end{array}$} & \multirow{2}{*}{$\begin{array}{l}\text { Time, } \\
\min \end{array}$} & \multirow[t]{2}{*}{$\mathrm{pH}$} & \multirow[t]{2}{*}{ Remarks } \\
\hline & Materials & $\begin{array}{c}\text { Dosage, } \\
\%\end{array}$ & Materials & $\begin{array}{c}\text { Dosage, } \\
\%\end{array}$ & & & & \\
\hline \multirow[t]{3}{*}{ Pickling } & Water* & 80 & Water & 80 & & & $2.5-$ & \\
\hline & Sodium* & 8 & Sodium Chloride & 8 & 25 & 25 & 2.8 & \\
\hline & $\begin{array}{l}\text { Chloride* } \\
\text { Sulfuric Acid* }\end{array}$ & 1.2 & Sulfuric Acid & 1.2 & & 60 & & \\
\hline \multirow[t]{2}{*}{ Tanning } & \multirow{2}{*}{$\begin{array}{l}\text { Chrome } \\
\text { tanning agent } \\
\text { (in conversion } \\
\text { forCr }_{2} \mathrm{O}_{3} \text { ) }\end{array}$} & 1.5 & $\begin{array}{l}\text { Chrome tanning agent } \\
\text { (in conversion for } \\
\mathrm{Cr}_{2} \mathrm{O}_{3} \text { ) }\end{array}$ & $\begin{array}{l}0.5- \\
1.0^{* *}\end{array}$ & 25 & 60 & & \\
\hline & & & $\begin{array}{l}\text { Modified } \\
\text { montmorillonite } \\
\text { dispersions }\end{array}$ & $\begin{array}{c}2.5^{-} \\
3.5^{* *}\end{array}$ & 25 & 120 & & \\
\hline Basification & $\begin{array}{l}\mathrm{S} \text { o d i u m } \\
\text { bicarbonate }\end{array}$ & 1.5 & Sodium bicarbonate & 1.5 & 25 & $2 \times 20+30$ & $\begin{array}{l}3.7- \\
4.0\end{array}$ & overnight \\
\hline
\end{tabular}

* - All materials dosage used were based on limed pelts after weight

** - Dosing of materials was carried out according to the variant of treatment of the Table 1.

The Degree of Absorption of Chromium Compounds in the Wastewater

The degree of absorption of chromium compounds in the wastewater was determined using a ULAB 102UV spectrophotometer (China). For this purpose, $10 \mathrm{ml}$ of tanning wastewater was selected and initial $\left(C_{0}\right)$ and final $\left(C_{f}\right)$ concentrations of $\mathrm{Cr}_{2} \mathrm{O}_{3}$ in the working fluid were evaluated using a previously obtained calibration curve. The degree of absorption of chromium compounds (\%) during tanning was calculated by the formula (2):

$x=\frac{\mathrm{C}_{0}-\mathrm{C}_{f}}{\mathrm{C}_{0}} \times 100 \%$, $\mathrm{g} / \mathrm{l}$;

where $\mathrm{C}_{0}$ - is the initial concentration of $\mathrm{Cr}_{2} \mathrm{O}_{3^{\prime}}$

$\mathrm{C}_{\mathrm{f}}$ - is the final (equilibrium) concentration of $\mathrm{Cr}_{2} \mathrm{O}_{3}, \mathrm{~g} / \mathrm{l}$.

\section{The Analysis of the Leathers after Chrome and Chrome-less Tanning}

The analysis of the leather has been conducted using the official (IULTCS International Union of Leather Technologists and Chemists Societies) methods.

The effect of $\mathrm{MMT}_{\mathrm{Al}}$ dispersion on the stabilization of the derma collagen structure was evaluated by the yield of the leather by area, 
thickness, yield of weight and hydrothermal stability (shrinking temperature).

The Thickness and the Area of Leather and Yield of Weight of Leather

The thickness and the area of the leather were measured after chrome-tanning for control samples and after chrome-less tanning by the various experimental treatments (Table 1 ). The determination of leather thickness was performed according to (ISO 2589: 2019) and area (ISO 11646: 2014).

The thickness or area of experimental leather samples can be calculated based on the fact that the thickness or the area of control leather samples were $100 \%$.

The yield of weight of leather can calculated as the equation (3): $x=\frac{m}{l \times S}$,

where, $\mathrm{m}$ - is the mass of the samples, $\mathrm{g} ; \mathrm{I}$ - is the average thickness of the samples, $\mathrm{cm} ; \mathrm{S}$ - is the area of the samples, $\mathrm{cm}^{2}$.

\section{Shrinking Temperature}

The shrinking temperature of the leather samples was tested according to the International Standard Test Method (ISO 3380:2015).

\section{Chemical and Physical-Mechanical Properties}

Indicators of chemical and physicalmechanical properties of the leather were evaluated according to standard methods [23] and regulatory requirements for the upper shoe leather [24] (Table 3).

Table 3: Indicators of chromium tanning leather

\begin{tabular}{lll}
\hline № & Indicator & Value \\
\hline & Content in leather, \%: & \\
1 & - moisture & $10.0-16.0$ \\
& - chromium oxide (III)* & no less 3.7 \\
& - substances extracted with organic solvents* & $3.7-10.0$ \\
2 & Tensile strength, ${ }^{*} 10 \mathrm{MPa}$ & no less 1.4 \\
3 & Elongation at $9,8 \mathrm{MPa}$ load, \% & $15-35$ \\
\hline
\end{tabular}

*- \% on absolutely dry substance

Content of Moisture, Minerals, Protein and Chromium Oxide

Determination of the moisture, protein and mineral content was tested according to the light industry standard methods [23]. The content of chromium oxide in the leather samples was determined according to ISO 5398-1.

\section{Tensile Strength and Elongation at Load of Leather}

The tensile strength and elongation at load of all the leathers were tested in accordance with the ISO 3376:2011.

\section{Air Permeability and Water-Absorption by Capillary Action}

Analysis of the leather samples' air permeability was tested according to the light industry standard methods [23]. Analysis of the leather water-absorption by capillary action according to (ISO 19074:2015).

\section{RESULTS AND DISCUSSIONS}

\section{Rheological Properties of Montmorillonite Dispersion}

The characteristic rheological properties of modified montmorillonite dispersions are manifested in changes in viscosity and $\mathrm{pH}$ levels from the consumption of the modifiers (Figure 1). 


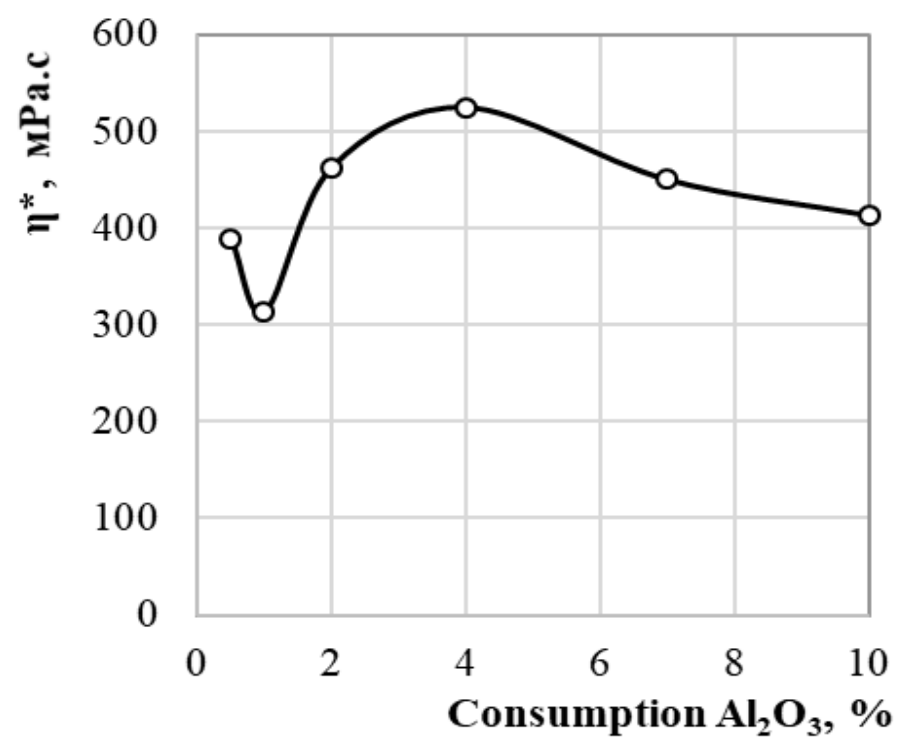

Figure 1. The curve of dependence of plastic viscosity on the concentration of $\mathrm{Al}_{2} \mathrm{O}_{3}, 0.5 ; 1.0 ; 2.0 ; 4.0$; $7.0 ; 10.0 \%$

The results of the plastic viscosity of the montmorillonite dispersion indicate that with increasing consumption of $\mathrm{Al}_{2} \mathrm{O}_{3}$ up to the level of $4.0 \%$, the mineral exchange capacity of the mineral is completely saturated. Further increase of $\mathrm{Al}_{2} \mathrm{O}_{3}$ concentration to $7.0 \%$ is characterized by a sharp decrease in viscosity, which indicates the peptization of the dispersion. Given the above, it can be noted that at low concentrations of $\mathrm{Al}_{2} \mathrm{O}_{3}$ on the surface of the particles of montmorillonite, a gradual adsorption occurs (Figure 1). Aluminum cations first neutralize the charge of the surface of the mineral particles (consumption 0.5 - 4.0 $\%$ of $\left.\mathrm{Al}_{2} \mathrm{O}_{3}\right)$, and then recharge the surface to the cationic form (consumption $5.0-10.0 \%$ of $\left.\mathrm{Al}_{2} \mathrm{O}_{3}\right)$.

Obtaining the most stable, peptized dispersions of montmorillonite occurs at the expense of aluminum compounds in conversion for $\mathrm{Al}_{2} \mathrm{O}_{3}$ within $5.0-7.0 \%$. Increase of the aluminum compounds consumption to $10.0 \%$ of $\mathrm{Al}_{2} \mathrm{O}_{3}$ results in a significant peptization of the dispersions and a decrease in the viscosity of the modified dispersions. At the same time, the modified dispersions are characterized by a stable $\mathrm{pH}$ level within 3.0-3.5 at the corresponding $\mathrm{Al}_{2} \mathrm{O}_{3}$ consumption. Such positively charged rarefied $\mathrm{MMT}_{\mathrm{Al}}$ dispersions will be used in further studies.

\section{Adsorption Aluminum Compounds on Surface of Montmorillonite}

The modification of montmorillonite dispersions by aluminum compounds not only alters the rheological behavior but also affects the adsorption properties of the mineral. According to the results of studies (Figures 2, 3) it is revealed that a rapid increase of adsorption on the surface of montmorillonite at the consumption of aluminum compounds up to 7.0 $\%$ of $\mathrm{Al}_{2} \mathrm{O}_{3}$. In addition, the adsorption feature of aluminum compounds is in accordance to the Langmuir isotherm [25]. It can be assumed that the ion-exchange substitution of $\mathrm{Na}^{+}$- ions initially occurs in the dispersion of hydroxocations of $\mathrm{Al}^{+3}$ on the surface of the mineral particles. As a result, charge neutralization and surface cation of the montmorillonite particles occur and subsequent adsorption of aluminum compounds occurs.

Further increase in the consumption of aluminum compounds up to $10-20 \%$ of $\mathrm{Al}_{2} \mathrm{O}_{3}$ causes a slight increase in adsorption, which can be confirmed by the increase of complex formation on the surface of the modified montmorillonite and in solution. 


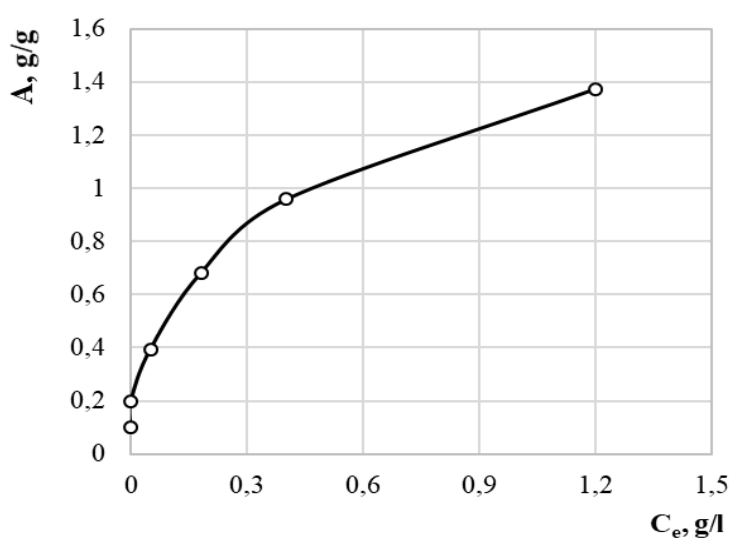

Figure 2. The adsorption level of aluminum compounds on the surface montmorillonite depending consumption of $\mathrm{Al}_{2} \mathrm{O}_{3}$

A visual study of the modified montmorillonite dispersions with different consumption of aluminum compounds (Figure 3 ), shows that at a concentration of $1.0-2.0 \%$ of $\mathrm{Al}_{2} \mathrm{O}_{3}$, the full saturation of the exchange capacity of montmorillonite is ensured. The coloration of the solutions by adding an aluminon indicator in bright red at a consumption level of 7.0-20.0 \% of $\mathrm{Al}_{2} \mathrm{O}_{3}$ indicates that the complete saturation of the exchange capacity of montmorillonite is reached and the aluminum compounds are found to be in excess. The presence of excessive amounts of aluminum compounds in the montmorillonite dispersion may contribute to additional action tannin on the derma collagen during tanning.

At the same time, $5.0-7.0 \% \mathrm{Al}_{2} \mathrm{O}_{3}$ of the weight of the mineral can be considered the optimal consumption of potassium aluminum sulfate for modified montmorillonite dispersion. Under these conditions, diluted positively charged montmorillonite dispersions are obtained, which can be effectively applied in the tanning process.

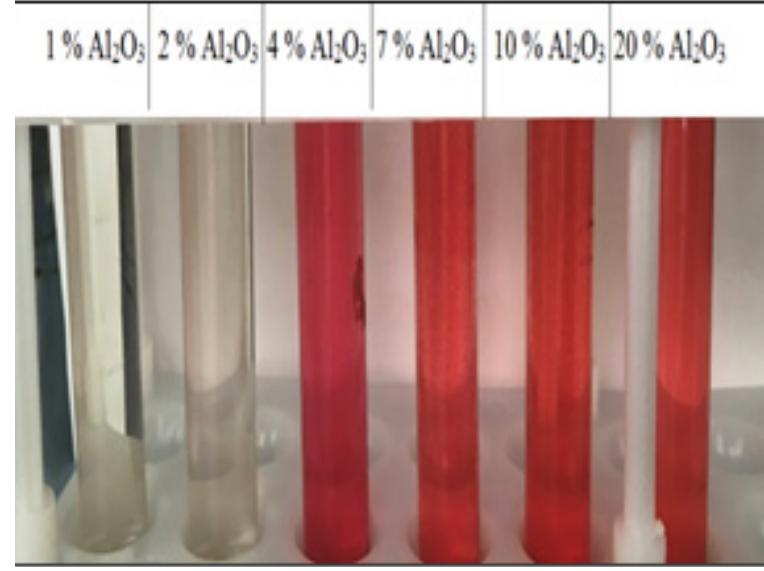

Figure 3. The adsorption of aluminum compounds on the surface montmorillonite depending consumption of $\mathrm{Al}_{2} \mathrm{O}_{3}$

\section{Interaction of Modified Montmorillonite Dispersion with Collagen of Derma}

\section{Interaction of Modified Montmorillonite Dispersions on Melting Temperature of Gelatin}

The results of the studies show an increase in the level of melting temperature of gelatin after treatment of aluminum compounds with tannins (Figure 4) and modified montmorillonite dispersion (Figure 5), which indicates a change in the state of the internal structure of gelatin. The results of melting temperature studies are presented in Figures 4-5.

Analysis of the results of the melting temperature for the $\mathrm{G}+\mathrm{Al}$ and $\mathrm{G}+\mathrm{Al}+\mathrm{HCOONa}$ experiments indicates two distinctive features. At a consumption of $1.0-4.0 \%$ of $\mathrm{Al}_{2} \mathrm{O}_{3}$ of the weight of gelatin for the $\mathrm{G}+\mathrm{Al}$ experiment, the melting temperature rises to $45.6^{\circ} \mathrm{C}$. However, a further increase of $\mathrm{Al}_{2} \mathrm{O}_{3}$ consumption in the range of $7.0-20.0 \%$ of $\mathrm{Al}_{2} \mathrm{O}_{3}$ of the weight of gelatin leads to a gradual decrease of the indicator to the level of $40.8-37.8^{\circ} \mathrm{C}$, which is $17 \%$ less than the maximum value. The melting temperature of gelatin without treatment with aluminum compounds was $36.7^{\circ} \mathrm{C}$. 


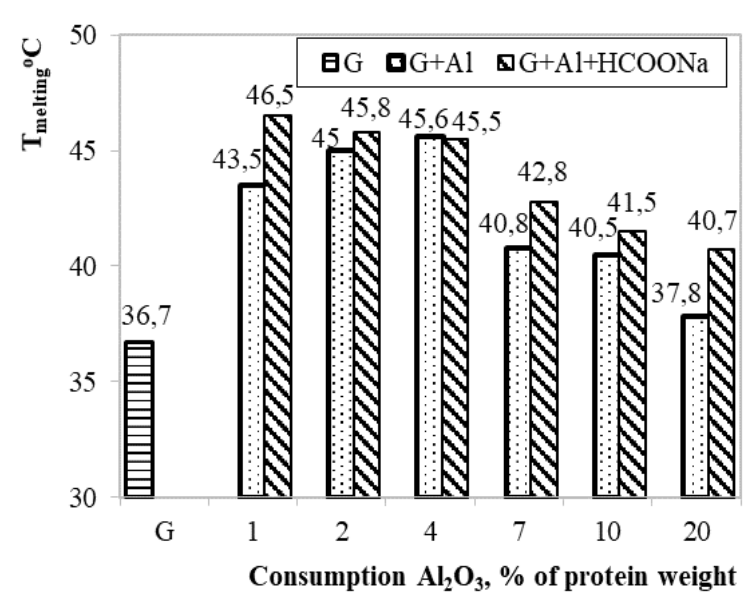

Figure 4. Melting temperature of gelatin after treatment of aluminum compounds and with fixing sodium formate

For $\mathrm{G}+\mathrm{Al}+\mathrm{HCOONa}$ experiments, an increase in the level of gelatin melting temperature compared to $\mathrm{G}+\mathrm{Al}$ experiment was observed, indicating an increase in the complexation in the protein system [16]. In general, increasing the consumption of aluminum compounds more than $7.0 \%$ of $\mathrm{Al}_{2} \mathrm{O}_{3}$ of the weight of gelatin is not advised, since there is a decrease in the melting temperature of gelatin in all situations. This may be due to the destabilization of the gelatin structure and the decrease in the $\mathrm{pH}$ of the medium owing to the presence of a large number of sulfogroups in the potassium aluminum sulfate, which causes a peptization of the gelatin system.

A study of the melting temperature of the $\mathrm{G}+\mathrm{MMT}_{\mathrm{Al}}$ experiments (Figure 5) shows that the use of $\mathrm{MMT}_{\mathrm{Al}}$ dispersion promotes an increase in the melting temperature of gelatin. There is a structuring of gelatin at consumption above $7.0 \%$ of $\mathrm{Al}_{2} \mathrm{O}_{3}$ of the weight of the mineral. Given that $2.5 \%$ of the mineral dispersion was used to process gelatin in conversion for mineral weight, and the consumption of modifying montmorillonite was $1.0-20.0 \%$ of $\mathrm{Al}_{2} \mathrm{O}_{3}$, the result of calculating the consumption of $\mathrm{Al}_{2} \mathrm{O}_{3}$ of the weight of gelatin was only 0.025-0.5\%. Thus, even at such minimum consumption of aluminum compounds, it is possible to increase the melting temperature of gelatin by $10-14 \%$ compared to untreated gelatin. The introduction of modified montmorillonite dispersions promotes complex transformation of the collagen structure.

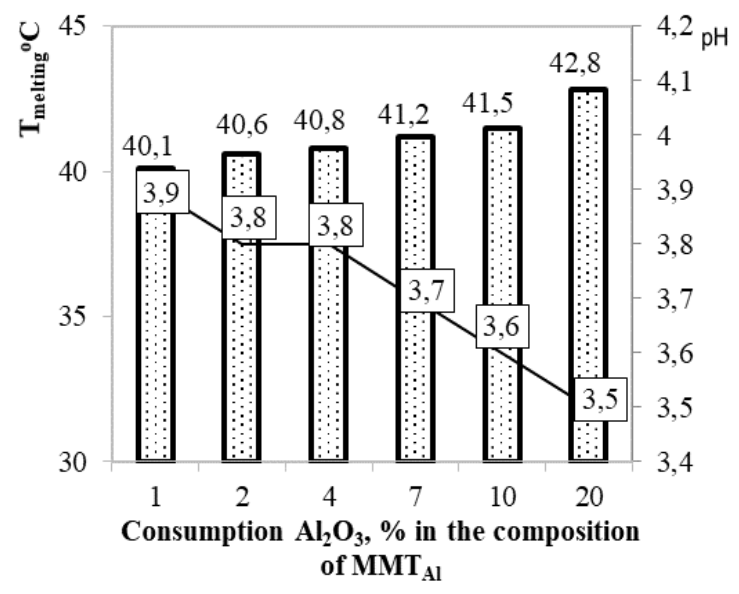

Figure 5. Dependence of the melting temperature of $\mathrm{G}+\mathrm{MMT}_{\mathrm{Al}}$ and $\mathrm{pH}$ on the consumption of aluminum compounds

This creates the formation of chemical bonds between collagen, chromium tanning agent, aluminum tanning agent and montmorillonite.

The $\mathrm{pH}$ is at 3.5-3.9, which is optimal for tanning. Therefore, the results of the analysis of the melting temperature of the gelatin after treatment with $\mathrm{MMT}_{\mathrm{Al}}$ dispersions indicate the possibility of their use for leather tanning. In order to more effectively structure and increase the level of derma collagen resistance in the process, it is advised to use modified montmorillonite dispersions with other tannins. Considering that aluminum tanning does not provide high hydrothermal resistance of derma [20], it is advised to use combined tanning using chromium compounds.

\section{Identification of Chemical Interactions between} Collagen Derma and Modified Montmorillonite

Spectra of $\mathrm{G}_{\mathrm{MMT}} \mathrm{Ml}_{\mathrm{Al}}$ (Figure 6) are different from the spectra of the G+Al sample in the range of valence $-\mathrm{NH}$ fluctuations of nitrogen-containing groups of gelatin and valence vibrations of structuring hydroxyl groups $\mathrm{Al}(\mathrm{OH})_{3}$. The band of $3462 \mathrm{~cm}^{-1}$ is related to $\mathrm{OH}-$ vibrations of the molecules of absorbed water that take part in hydrogen bonds. Appearance of the medium peak at $3387 \mathrm{~cm}^{-1}$ and more intensive at $3354 \mathrm{~cm}^{-1}$ for the sample $\mathrm{G}+\mathrm{MMT}_{\mathrm{Al}}$ indicate the interlayer exchange cations and are proved by the existence of maximum in the IRrange at $3080 \mathrm{~cm}^{-1}$. 


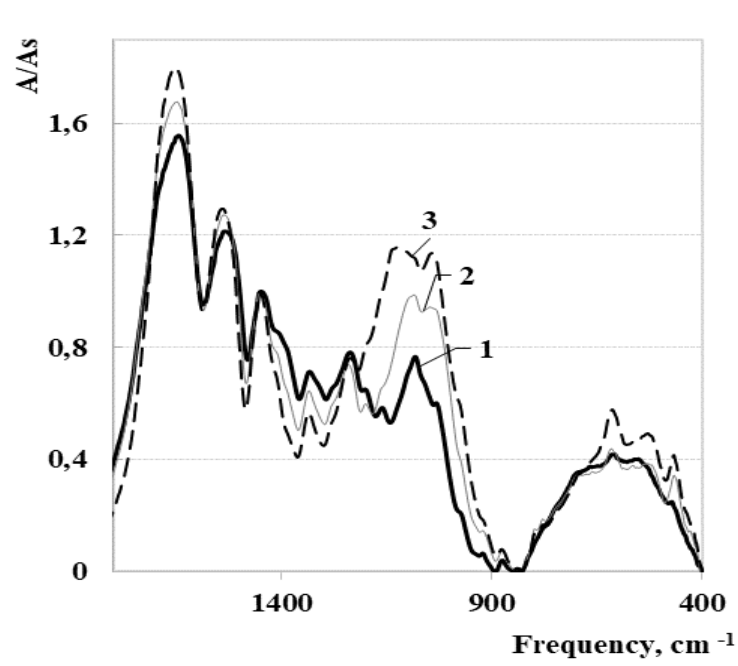

$a$

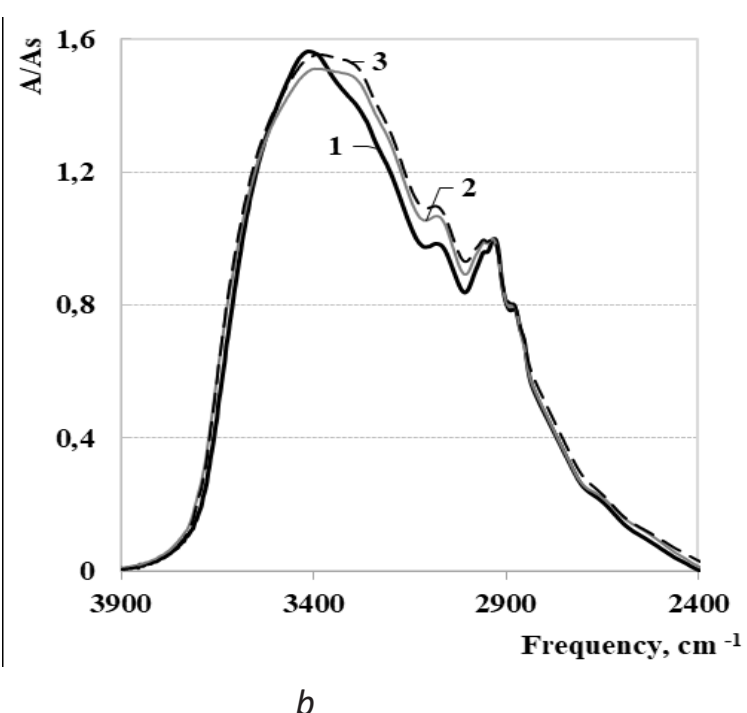

$b$

Figure 6. Characteristic absorption bands of $\mathrm{G}(1), \mathrm{G}+\mathrm{MMT}_{\mathrm{Al}}(2), \mathrm{G}+\mathrm{Cr}+\mathrm{MMT}_{\mathrm{Al}}$ (3) in the frequency range: $a-3900-2400 \mathrm{~cm}^{-1} ; b-1900-400 \mathrm{~cm}^{-1}$

The bands of valence fluctuations of Amides I, II and III for the G+MMT Al sample reveal a certain influence on the structure of gelatin. In this case, the area under the peaks of $1663 \mathrm{~cm}^{-1}$, $1532 \mathrm{~cm}^{-1}$ and $1241 \mathrm{~cm}^{-1}$ decreases in comparison with maxima in the spectrum of the $\mathrm{G}$ sample.

In the spectral range of $1161-1016 \mathrm{~cm}^{-1}$, valence fluctuations of $\mathrm{CN}$-groups, sulfogroups and $\mathrm{NH}_{3}{ }^{+}$vibrations of gelatin, valence fluctuations of $\mathrm{Si}(\mathrm{OH}) \mathrm{Al}$, as well as vibrations of free surface deformation of $\mathrm{OH}$-groups of $\mathrm{SiO}$ vibrations are manifested for the sample G+MMT ${ }_{\mathrm{Al}}$.

In the range of spectrum of $780-615 \mathrm{~cm}^{-1}$ for the $\mathrm{G}+\mathrm{MMT}_{\mathrm{Al}}$ sample, there are the bands of valence fluctuations and deformation vibrations of peptides (Amide $\mathrm{V}$ and Amide $\mathrm{VI}$ ) and the aluminum complex. In the spectrum of the $\mathrm{G}+\mathrm{MMT}_{\mathrm{Al}}$ sample, the wide absorption band is divided into four maxima at $780 \mathrm{~cm}^{-1}, 699 \mathrm{~cm}^{-}$ $1,659 \mathrm{~cm}^{-1}$ and $615 \mathrm{~cm}^{-1}$. This can indicate the participation of $\mathrm{OH}$-groups in the formation of hydrogen interaction $\mathrm{Si}-\mathrm{OH} \cdots \mathrm{O}-\mathrm{C}$.

Appearance of peaks of $525 \mathrm{~cm}^{-1}$ and 426 $\mathrm{cm}^{-1}$ for the $\mathrm{G}+\mathrm{MMT}_{\mathrm{Al}}$ sample, which characterize deformation vibrations of $\mathrm{C}=\mathrm{O}$-groups, $\mathrm{O}-\mathrm{Si}-\mathrm{O}$ and valence fluctuations of Al-O may indicate the formation of hydrogen bonds between the functional groups of gelatin and $\mathrm{MMT}_{\mathrm{Al}}$ of the $\mathrm{Si}-\mathrm{O} \ldots . \mathrm{H}-\mathrm{N}$ type with $\mathrm{NH}$-groups of protein and $\mathrm{Si}-\mathrm{O}$.... H-C with $\mathrm{CH}$-groups of protein [18].

For the spectrum of the sample of $\mathrm{G}+\mathrm{Cr}+\mathrm{MMT}_{\mathrm{Al}}$ (Figure 6), valence fluctuations of $\mathrm{OH}$-groups in the range of $3400 \mathrm{~cm}^{-1}$ are the most sensitive to the presence of hydrogen bonds. Their location depends on the concentration of water, conditions of obtaining the spectra that are easily separated from the absorption bands of other groups [21].

In the IR-spectrum of the $\mathrm{G}+\mathrm{Cr}+\mathrm{MMT}_{\mathrm{Al}}$ sample, adsorption moisture is characterized by wide absorption bands in the interval of $3500-3000 \mathrm{~cm}^{-1}$. A wide adsorption band with two peaks at 3391 and $3379 \mathrm{~cm}^{-1}$ shifted to the low-frequency region, but with a larger area in comparison with the $\mathrm{G}+\mathrm{MMT}_{\mathrm{Al}}$ sample, is caused by valence vibrations of $\mathrm{H}$-bound $\mathrm{OH}$-groups and their compactness. This fact is proved by a decrease in the sample of weakly bound moisture, characterized by the peak maximum at $3077 \mathrm{~cm}^{-1}$ (Figure 6a).

Results of analysis of the spectra of the $\mathrm{G}+\mathrm{Cr}+\mathrm{MMT}_{\mathrm{Al}}$ have more active coordination bonds between chrome and $\mathrm{OH}$-groups of protein. It is also proved by the interval of the spectrum of 1667-1242 $\mathrm{cm}^{-1}$, which characterizes the existence of valence groups of Amides I, II and III (Figure 6b). At the same time, bands of $1119-1041 \mathrm{~cm}^{-1}$ correspond to vibrations $\mathrm{C}-\mathrm{N}$ of valence groups, $\mathrm{NH}$ and $\mathrm{NH}_{3}^{+}$ deformation vibrations, as well as sulfogroups of chromium and aluminum complexes.

The shift of the peak of $1041 \mathrm{~cm}^{-1}$ by $25 \mathrm{~cm}^{-1}$ to the high-frequency range, as well as the shift of the bands of 754 and $609 \mathrm{~cm}^{-1}$ and an increase in their area, which is characteristic of $\mathrm{COO}^{-}, \mathrm{Me}-\mathrm{O}$ groups (Figure 6b), can indicate the formation 
of coordination bonds mainly between the ions of chromium and carboxylic groups $-\mathrm{COOH}$ of the side chains of gelatin. Also, the predicted strengthening of the structure of the treated gelatin may be a manifestation of the increase in siloxane groups caused by the hydroxo-complex ions $\mathrm{Cr}$ (III) and $\mathrm{Al}$ (III) located between the silicate layers of the mineral due to compression of the $\mathrm{OH}$ groups. As a result of a comprehensive study of the chemical interactions of modified montmorillonite dispersions with collagen, it is possible to state the feasibility of using modified montmorillonite dispersions for leather tanning.

\section{Results of the Tanning Performance}

An analysis of the degree of absorption of chromium compounds during tanning (Table
4) indicates that the highest absorption level at $86.9 \%$ is distinctive to treatment option 3 . The control treatment 1 is characterized by a lower absorption rate of $65.8 \%$. For option 4 , the absorption rate was $82.2 \%$. Meanwhile, the initial consumption for chromium compounds was 3 times lower than that of the control treatment. The use of the modified montmorillonite changes the mechanism of chromium tanning. The spatial structure of the mineral and its large specific surface area create additional active centers for the chemical interaction of aluminum and chromium compounds with collagen of the derma. Montmorillonite particles enhance the adsorption and fixation of chromium compounds in the structure of the derma, which increases their degree of absorption in the derma.

Table 4: Analysis of wastewaters

\begin{tabular}{ccccc}
\hline \multirow{2}{*}{ Index } & \multicolumn{4}{c}{ Variant of treatment } \\
& 1 control & 2 & 3 & 4 \\
\hline The degree of absorption of chromium compounds, $\%$ & 65.8 & 81.5 & 86.9 & 82.2 \\
\hline
\end{tabular}

For the control and experimental samples, an organoleptic analysis was performed. It was found that all the experimental samples (treatment options 2-4) were fuller, more elastic and softer compared to the control samples.

After modification the dispersion of montmorillonite contain polydisperse particles. Nano- (53.8-67.7 nm) and micro- (388.0$472.1 \mathrm{~nm}$ and 913.8-1128.0 nm) particles are present in the dispersion [26]. The modified montmorillonite dispersions can provide the formation of the derma structure at the level of fibrils and fibers [27]. At the same time screening of the structural elements of the derma is happening, which prevents them from sticking together, increases the area, thickness of the leather and improves the formation of the volume of the derma (Table 5).

Indicators of structure formation of the obtained leather are presented in Table 5 and estimated by the level of yield of leather thickness, area and shrinking temperature (Table 5).

Table 5: Indicators of structure formation of the derma

\begin{tabular}{|c|c|c|c|c|}
\hline \multirow{2}{*}{ Index } & \multicolumn{4}{|c|}{ Variant of treatment } \\
\hline & 1 control & 2 & 3 & 4 \\
\hline \multicolumn{5}{|l|}{ Yield of leather, \% } \\
\hline - area & 100.0 & 104.4 & 105.9 & 102.6 \\
\hline - thickness & 100.0 & 104.4 & 108.5 & 108.4 \\
\hline Yield of weight, $\mathrm{g} / \mathrm{cm}^{3}$ & 0.462 & 0.497 & 0.511 & 0.485 \\
\hline Shrinking temperature, ${ }^{\circ} \mathrm{C}$ & 103 & 102 & 102 & 101 \\
\hline
\end{tabular}

An analysis of the derma structure formation indices (Table 5) shows that all prototypes have increased yield of leather area and yield of leather thickness. The biggest increase in thickness corresponds to the treatment options 3 and 4 . The sample 3 is characterized by an increase of $5.9 \%$ of the area output. This may be connected with the use of modified montmorillonite tannin composition on its effect on the formation of derma collagen structure.

Furthermore, almost identical hydrothermal stability as in the control of $103^{\circ} \mathrm{C}$ is achieved for all experimental options of treatment at lower consumption of chromium compounds during the tanning process. In this case, the decrease of consumption of chromium 
tanning agents by $33-67 \%$ in the experimental treatment will facilitate the rational use of chromium compounds and ecologization of the leather manufacturing.

The analysis of the chemical composition of the samples (Table 6) shows that the moisture content in all the experimental samples meets the standard requirements [24]. Due to the use of montmorillonite dispersions during the tanning process, the content of mineral substances is higher in the experimental samples and forms 11.0-11.6\% compared to the control samples. In addition, in the control samples, the content of the protein substance was $2.4-3.1 \%$ higher than in the experimental samples. This can serve as evidence of better structuring and formation of the derma using a modified montmorillonite.

Analysis of the content of $\mathrm{Cr}_{2} \mathrm{O}_{3}$ in the leather shows that all samples meet the standard requirements (Table 3 ). In this case, the control samples contain $4.4 \%$ of chromium oxide (Table 6) and have a low degree of adsorption of chromium compounds during tanning (Table 4). It should be noted that the content of $\mathrm{Cr}_{2} \mathrm{O}_{3}$ in leather from variants of treatment 3 and 4 is quite high at 50 $67 \%$ lower consumption of chromium tanning agent at the beginning of tanning compared to the control. The high content of chromium compounds in leather is the result of a more effective interaction of chromium compounds with the collagen of the derma. This is due to the presence of additional active centers of modified montmorillonite, which enhance the chemical interaction of the tanning agents.

As a consequence, chromium compounds in the derma structure are better bonded and fewer compounds get into the wastewater.

Table 6: Indicators of the chemical composition of the leather

\begin{tabular}{lcccc}
\hline \multicolumn{1}{c}{ Indicator } & \multicolumn{2}{c}{ Variant of treatment } \\
& 1 control & 2 & 3 & 4 \\
\hline Content in leather, \%: & & & \\
- moisture & 14.5 & 14.2 & 14.1 & 13.8 \\
- mineral substances* & 10.7 & 11.6 & 11.0 & 11.1 \\
- $\mathrm{Cr}_{2} \mathrm{O}_{3}{ }^{*}$ & 4.4 & 4.1 & 4.2 & 3.8 \\
- protein substance* & 64.7 & 62.3 & 62.0 & 61.6 \\
- substances extracted with organic solvents * & 6.7 & 6.8 & 6.5 & 6.4 \\
\hline *
\end{tabular}

* in conversion for absolutely dry substance

Moreover, the physical-mechanical properties of the obtained leather samples were investigated. According to the test results (Table
7), the control and experimental samples meet the standard requirements [24].

Table 7: Indicators of physical-mechanical properties of leather

\begin{tabular}{|c|c|c|c|c|}
\hline \multirow{2}{*}{ Indicator } & \multicolumn{4}{|c|}{ Variant of treatment } \\
\hline & 1 control & 2 & 3 & 4 \\
\hline Tensile strength, $\times 10 \mathrm{MPa}$ & 1.85 & 1.95 & 2.01 & 1.92 \\
\hline Elongation at 9,8 MPa load, \% & 35,6 & 29,4 & 31,5 & 31,3 \\
\hline Specific elongation at rupture, \% & 57.4 & 49.0 & 51.8 & 54.4 \\
\hline Conditional modulus of elasticity, $\mathrm{H} / \mathrm{m}^{2}$ & 0.43 & 0.32 & 0.26 & 0.29 \\
\hline Rigidity, $\mathrm{H}$ & 5.1 & 4.9 & 4.8 & 4.9 \\
\hline
\end{tabular}

The data analysis in Table 7 shows that the level of tensile strength in the experimental samples is higher by $3.8-8.7 \%$ than that of the control. In addition, the use of the modified montmorillonite dispersion during the tanning reduces the elongation at $9.8 \mathrm{MPa}$ load of on $11.5-17.4 \%$ and at rupture of $5.2-14.6 \%$ for the experimental samples compared with the control samples. Experimental samples have a lower level of rigidity and conditional modulus of elasticity compared to the control, which confirms the effectiveness of the use of the modified montmorillonite dispersion.

It is proved that the use of modified montmorillonite dispersion for tanning also affects the formation of hygienic properties of the leather (Table 8). As a result of the introduction of modified montmorillonite dispersion, the resistance to water-absorption by capillary action fractionally increases (except for the option 2). All samples have a high level of relative air permeability. 
Table: 8 Hygienic properties of the leather

\begin{tabular}{ccccc}
\hline \multicolumn{1}{c}{ Indicator } & \multicolumn{3}{c}{ Variant of treatment } \\
\hline $\begin{array}{c}\text { Water-absorption by capillary action, \%: } \\
\quad \text { - after 2 hours }\end{array}$ & 1 control & 2 & 3 & 4 \\
$\quad$ - after 2 and 24 hours & 182.3 & 188.6 & 175.1 & 169.3 \\
Relative air permeability, $\mathrm{cm}^{3} / \mathrm{cm}^{2} \times$ hours & 191.3 & 191.6 & 179.8 & 177.9 \\
\hline
\end{tabular}

As a consequence of the leather quality analysis, $0.75 \%$ of $\mathrm{Cr}_{2} \mathrm{O}_{3}$ and $3.0 \%$ of the modified montmorillonite dispersion in conversion for the mineral content of the weight of the pelts (variant of treatment 3) can be considered the optimal consumption of chromium tanning agent. The use of modified montmorillonite combined with tanning basic chromium sulphate (III) allows to obtain leather with increased yield in area and thickness, sufficient level of structuring, required indices of physical-mechanical properties and chemical composition, reduced rigidity and increased resistance.

\section{CONCLUSION}

The paper is devoted to the study of modified montmorillonite dispersion properties in order to develop a chrome-less method of tanning. It is proposed to modify montmorillonite with aluminum compounds and to combine the obtained dispersions with chromium compounds.

It is proved that modification of montmorillonite dispersions by aluminum compounds within 5.0-7.0 \% $\mathrm{Al}_{2} \mathrm{O}_{3}$ of the weight of the mineral contributes to obtaining the most stable positively charged montmorillonite dispersions. The obtained dispersions are characterized by a stable $\mathrm{pH}$ level in the range of 3.5-4.0, which is predicted to allow an efficient tanning process.

Analysis of the temperature resistance of gelatin indicates that the use of montmorillonite dispersions is effective for stabilizing collagen structure. To increase the level of derma collagen resistance in the process, it is advised to use modified montmorillonite dispersions in combination with other tannins.

Conducted studies on the chemical interactions between collagen of derma and modified montmorillonite dispersions have revealed the formation of chemical bonds involving aluminum between the collagen side chains and the hydroxyl groups of molecules of already bound peptides of pre-chromed gelatin. A combination of chemical interactions enables the formation of hydrogen, ionic and covalent bonds, which increases the efficiency of collagen structuring.

It has been confirmed that the use of montmorillonite modified using the aluminum compound for tanning contributes to the effective structuring of the derma and the formation of the required leather quality. The use of modified montmorillonite dispersions combined with a chromium tanning agent contributes to the introduction of chrome-less tanning. At the same time, $0.75 \%$ of $\mathrm{Cr}_{2} \mathrm{O}_{3}$ and $3.0 \%$ of modified montmorillonite dispersion of the weight of the pelts in conversion for mineral weight are considered the optimal consumption of chromium tanning agents. The developed chrome-less tanning results in soft leather with increased yield of leather area, reduced rigidity, sufficient resistance to water-absorption and increased hydrothermal resistance. Meanwhile, the consumption of chromium compounds for tanning and their content in wastewater are reduced by approximately $20 \%$. This indicates that the use of modified montmorillonite dispersions increases the efficiency of chromium tanning use and promotes ecologization of leather manufacturing.

\section{REFERENCES}

1. Zhongkai, Z., Guoying, L., Bi, S., Physicochemical properties of collagen, gelatin and collagen hydrolysate derived from bovine limed split wastes, J Soc Leath Tech Ch, 2006, 1, 90, 23-29.

2. Zhaldak, M., Mokrousova, O., Stabilization of collagen structure with montmorillonite dispersions, Baltic Polymer Symposium 2019: Proceedings International Symposium: Vilnius, 2019, 93.

3. Covington, T., Tanning chemistry: The science of leather: RSC publishing, 2009. 
4. Ludvik, J., Chrome balance in leather processing. United Nations Industrial Development Organization (UNIDO), 2000, 18.

5. Zhou, J., Release of Chrome in Chrome Tanning and Post Tanning Processes, J Soc Leath Tech Ch, 2012, 4, 96, 157-162.

6. Zhao, Y.T., Wang, X.-C., Chinese developments in chrome-free and low-chrome tanning materials, J Soc Leath Tech Ch, 2007, 91, 246-251.

7. Danylkovych, A., Mokrousova, O., Zhegotsky, A., Improvement of the filling and plasticization processes of forming multifunctional leather materials, East-Eur J Enterp Technol, 2016, 2/6, 80, 23-31, https:// doi.org/10.15587/1729-4061.2016.65488.

8. Min, L., Jianzhong, M., Bin, L., Dangge, G., Jing, Z., Enhancement of chromium uptake in tanning process of goat garment leather using nanocomposite, J Clean Prod, 2016, 133, 487-494, https://doi.org/10.1016/j. jclepro.2016.04.156.

9. Essomba, J.S., Jaya, P.A., Placide Désiré, B.B., Ketcha, J.M., Nishter, N.F., Clay/polymer nanocomposites as filler materials for leather, J Clean Prod, 237, 2019, https://doi. org/10.1016/j.jclepro.2019.117837.

10. Uddin, F., Clays, nanoclays, and montmorillonite minerals, Metall Mater Trans, 2008, 39, 12, 2804-2814, https://doi. org/10.1007/s11661-008-9603-5.

11. Chen, Y., Shi, F., Shi, B., Nanotechnologies for leather manufacturing: A review, J Am Leather Chem As, 2011, 8, 261-273.

12. Sanchez-Olivares, G., Sanchez-Solis, A., Calderas, F., Sodium montmorillonite effect on the morphology, thermal, flame retardant and mechanical properties of semi-finished leather, Appl Clay Sci, 2014, 102, 254-260, https://doi.org/10.1016/j.clay.2014.10.007.

13. Bao, Y., Ma, J., Wangi, Y.-L., Preparation of acrylic resin/montmorillonite nanocomposite for leather tanning agent, J Am Leather Chem As, 2009, 104, 10, 352-358.

14. Marukhlenko, M., Mokrousova, O., Okhmat, O., New tanning agent with montmorillonite for leather manufacturing, Solid State Phenom, 2017, 267, 52-57, https://doi. org/10.4028/www.scientific.net/SSP.267.52.

15. Mokrousova, O., Danylkovich, A., Palamar, V., Resources-saving Chromium Tanning of Leather with the Use of Modified Montmorillonite, Rev Chim, 2015, 66, 3, 353-357.

16. Brown, E.M., Dudley, R.L., Approach to a tanning mechanism: Study of the interaction of aluminum sulfate with collagen, J Am Leather Chem As, 2005, 100, 10, 401-409.

17. Zhaldak, M., Mokrousova, O., Studying chemical transformations of the modified derma collagen. East-Eur J Enterp Technol, 2019, 4/6, 100, 1-15, https://doi. org/10.15587/1729-4061.2019.176006.

18. Gaidau, C., Applicative Chemistry of Tanning Metallic Heterocomplexes, Bentham Science Publishers, 2013, 188, https://doi.org/10.217 4/97816080574361130101.

19. Stuart, B., Editor D.J. Ando, Biological application of infrared spectroscopy: University of Greenwich, 1997, 212.

20. Sarver, R.W., Krueger, W.C., Protein secondary structure from Fourier transform infrared spectroscopy: A data base analysis, Anal Biochem, 1991, 194, 89-100, https://doi. org/10.1016/0003-2697(91)90155-M.

21. Derrick, M.R., Dusan, S., Landry, J.M., Infrared Spectroscopy in Conservation Science, 1999, 236.

22. Danylkovych, A., Mokrousova, O., Okhmat, O., Leather production technology and materials (in Ukrainian), 2009.

23. Danylkovych, A., Workshop on chemistry and technology of leather and fur (in Ukrainian), 2006.

24. DSTU 2726-94. Leather upper for shoes. Specifications (in Ukrainian), 1995, 14.

25. Tepmatee, P., Siriphannon, P., Effect of preparation method on structure and adsorption capacity of aluminium pillared montmorillonite, Mater Res Bull, 2013, 48, 11, 4856-4866, https://doi.org/10.1016/j. materresbull.2013.06.066.

26. Mokrousova, O., Moraru, V., Mineral fillers for leather. Rheological properties and dispersion of their aqueous suspensions (in Ukrainian), Bulletin of KNUTD, 2010, 4, 256-264.

27. Mokrousova, O., Dzyazko, Y., Volfkovich, Y., Nikolskaya, N., Hierarchical structure of the derma affected by chemical treatment and filling with bentonite: Diagnostics with a method of standard contact porosimetry, Nanophysics, Nanophotonics, Surface Studies and Applications. Part IV. Nanochemistry and Biotechnology, Springer Proceedings in Physics, 2016, 183, 277-290, http://doi. org/10.1007/978-3-319-30737-4_23.

(C) 2020 by the author(s). Published by INCDTPICPI, Bucharest, RO. This is an open access article distributed under the terms and conditions of the Creative Commons Attribution license (http:// creativecommons.org/licenses/by/4.0/). 